\title{
カロテノイドの吸収代謝と生理活性
}

\author{
寺尾 純二*1 . 長尾 昭彦*2 \\ $* 1$ 徳島大学医学部栄養学科食品学講座 \\ (下770-8503 徳島市蔵本町 3-18-15) \\ *2 農林水産省食品総合研究所食品理化学部脂質研究室 \\ （テ305-8642 つくば市観音台 2-1-2）
}
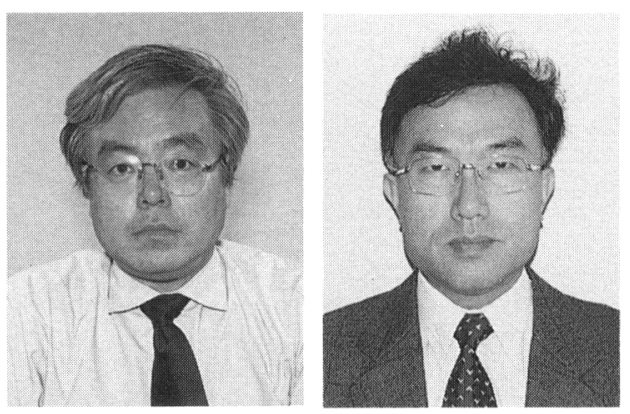

\section{Absorption, Metabolism and Physiological Functions of Carotenoids}

\author{
Junji Terao*1 and Akihiko NAGAO*2 \\ *1 Department of Nutrition, School of Medicine, The University of Tokushima \\ (3-18-25, Kuramoto-cho, Tokushima-shi 770-8503)
}

*2 Lipid Science Laboratory, National Food Research Institute, Ministry of Agriculture, Forestry and Fisheries

(2-1-2, Kannondai, Tsukuba-shi 305-8642) \begin{abstract}
proliferation
\section{1 研究の背景}

カロテノイドは長鎖の共役系二重結合を特徴とする一 群の色素の総称である。自然界には約 600 種類のカロテ ノイドが存在するが, その多くは炭素数 40 個のイソプ レン骨格で構成されている化合物である。ヒトが食物か ら攝取するカロテノイドは 40 種を越える程度であるが, ヒト血漿中にはそのうち 13 種類のカロテノイドやそれ らの代謝産物が存在することが知られている (Table 1)。 カロテノイドを構造から分類すると, 酸素分子を含まな い炭化水素カロテノイド（カロテン類やリコペンなど）
\end{abstract}

Abstract : Dietary carotenoids are absorbed from the digestive tract and distributed in tissues and fluids in the body. However, little is yet known on their physiological function, except for provitamin A activity. Antioxidant activity of carotenoids, including free radical scavenging and singlet oxygen quenching, has been well documented. Nevertheless, it is unclear whether or not this activity significantly contributes to the antioxidative defense system in vivo. Alternatively, the inhibition of cell proliferation and the induction of cell differentiation explain antitumorigenic effect of carotenoids in animal study. Enhancement of gap junctional communication may be also included in the effect of carotenoids. For the estimation of physiological function of dietary carotenoids, it is essential to understand their absorption and metabolism. 15,15'-Dioxygenase activity responsible for vitamin A activity is widely distributed in tissues and the absorption of carotenoids from digestive tract is significantly affected by diet factors. Finally their metabolic pathway is obscure although oxidative process is recently suggested.

Key words : carotenoids, absorption and metabolism, provitamin A, antioxidant, cell

連絡者：寺尾純二
と含酸素カロテノイド (キサントフィル類) に分類され る (Fig. 1) ${ }^{1)}$ 。またイオノン環の有無により, 環状力口 テノィド（カロテン類やキサントフィル類など）と非環 状カロテノイド（リコペンやフィトエン類）に分類する こともできる。

ところで, ヒト網膜黄斑に存在するカロテノイドはゼ アキサンチンとルテインのみである。ゼアキサンチンや ルテインに富む野菜果実の摄取により, 老人性網膜黄斑 変性症 (age-related macular degeneration：AMD) の発 症が有意に抑制されることが最近報告された2)。カロテ ノイドの生理活性として確実なものはプロビタミン $\mathrm{A}$ 活性であるが，ゼアキサンチンやルテインはプロビタミ

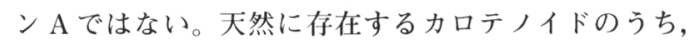


Table 1 Carotenoids Present in Human Plasma.

\begin{tabular}{ll}
\hline Provitamin A & non-provitamin A \\
\hline$\alpha$-carotene & $\alpha$-cryptoxanthin \\
$\beta$-carotene & neurosporene \\
$\gamma$-carotene & $\zeta$-carotene \\
$\beta$-cryproxanthin & phytofluene \\
& phytoene \\
& lycopene \\
& lutein \\
& zeaxanthin \\
& lactucaxanthin \\
\hline
\end{tabular}
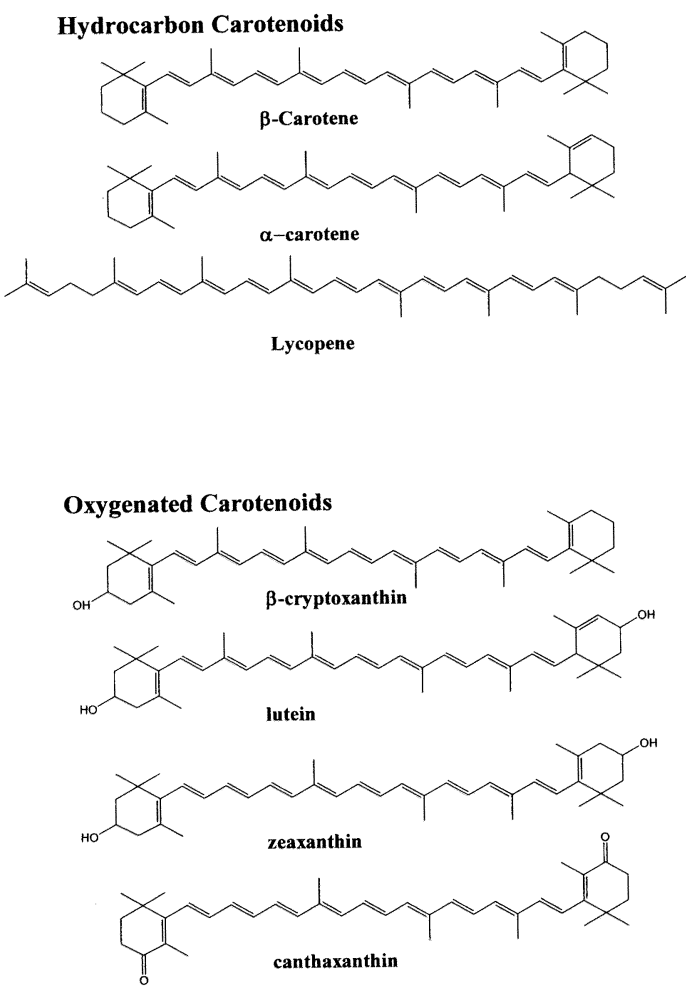

Fig. 1 Structures of Major Carotenoids.

ビタミン $\mathrm{A}$ 前駆体となるもの，すなわち酸化酵素（ジ オキシゲナーゼ）によりビタミン A に代謝変換される 構造を有するものは 30 種類程度にすぎない。一方，七 ト血漿にはプロビタミン $\mathrm{A}$ カロテノイドばかりでなく, ルテインやリコペンなどの非プロビタミン $\mathrm{A}$ カロテノ イドが存在することからわかるように, ヒトは食物由来 のカロテノイドをそのままの形で吸収し，体液や組織に 蓄積しやすい動物である。したがって，カロテノイドに はプロビタミン A 活性以外の生理機能が存在すると考 えるのは当然であり，そのひとつとして抗酸化活性が有 力視されている。しかし，現在でもその機能性が十分に
解明されているわけではない。

カロテノイドの抗酸化作用に関する報告は 1930 年代 からみられたが，一重項酸素 $\left({ }^{1} \mathrm{O}_{2}\right)$ 消去活性について は1968 年 Foote と Denny ${ }^{3)}$ が初めて発表した。現在で は，カロテノイドが強力な ${ }^{1} \mathrm{O}_{2}$ 消去物質であることはよ く知られた事実である。一方，カロテノイドのラジカル 捕捉能については Krinsky らの先駆的な報告 ${ }^{4}$ があった が，それほど注目されたわけではなかった。しかし， 及一カロテンはプロビタミン A 以外の作用でがん予防に 働くことを示唆した 1981 年の Peto らの論文発表5を端 緒として，カロテノイドの抗酸化作用に関する注目が俄 然高まった。その原因として，当時カロテノイドの生理 機能としてはプロビタミン $\mathrm{A}$ と抗酸化活性以外には知 られていなかったこと，活性酸素・フリーラジカルによ る生体の酸化障害が発がんを含む様々な疾病の要因とな ることがようやく認知されてきたことが挙げられる。 1984 年にカロテノイドの抗酸化作用に関する注目すべ

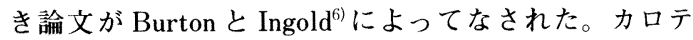
ノイドは生体内環境である低酸素状態において有効に作 用するラジカル捕捉剤であると彼らは考え，モデル実験 によりカロテノイドが低酸素分圧下で強いラジカル捕捉 活性を有することを示した。その後, カロテノイドがラ ジカル捕捉作用に基づく抗酸化活性を有することについ ては多くの実験的証拠が積み重ねられている。それにも 関わらず，カロテノイドの抗酸化活性が生理的意義をも ちうるのか，いいかえると本当に生体内抗酸化肪として 機能するか否かについては，確実な証明はなされていな い。むしろ，カロテノイドの酸化生成物が生理機能をも つという意味でのプロオキシダント作用も示唆されてい る。また，カロテノイドのレチノイド様物質への代謝変 換が機能性の発現に関わるという指摘もある。したがっ て，場合によっては抗酸化活性以外の活性がより重要で あるかもしれない。

一方, Petoらの研究5)を発端に, $\beta$-カロテンが発がん の化学予防物質として浮かびあがり， $\beta$-カロテンを対 象とした大規模なと卜介入試験が 1980 年代次々にス タートした。食道がんや胃がんの多発地域である中国河

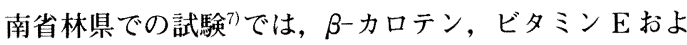
びセレンの服用群において総死亡率, 胃がん死亡率が有 意に低い結果が得られた。すなわち，これら抗酸化物質 のがん予防効果がヒトではじめて確認された。しかし， その後の多くの介入試験報告は, $\beta$-カロテンの有効性 を示すものではなかった。契煙者を対像としたフィンラ ンドにおける ATBC 研究8)や米国の CARET 研究9) は, $\beta$-カロテン服用群で肺がん発生率が逆に増加した ことが報告され, 数年前に大きな話題となった。米国医 師を対象としたPhysicians 研究10)では $\beta$-カロテン服用 でがん予防ばかりでなく心疾患予防にも効果がみられな 
かったことから，がんの化学䂆防物質としての $\beta$-カロ テンへの期待は萎えたようである。しかし，このことは 野菜や果実など食物から掑取されるカロテノイドの生理 機能を否定するものではない。介入試験の結果について は, 攝取量が多すぎたのではないか？ 摂取形態が食品 とは離れたものであり, しかも $\beta$-カロテン単一投与が 問題ではないか？ など様々な議論がある。いづれにし ても， $\beta$-カロテンの介入試験報告は, 野菜果実等の食 物から摂取したカロテノイドの機能発現機構に関する研 究の進展を促すものであると著者らは考えている。そこ で, 食物由来カロテノイドの吸収代謝および生理活性に 関する最近の研究報告のいくつかを我々の研究成果も交 えて以下に紹介したい。

\section{2 カロテノイドの吸収代謝}

ヒトは様々なカロテノイドを吸収・蓄積しその恩恵に あずかることができる。しかし，すべての哺乳動物が力 ロテノイドを蓄積できるわけではなく, 牛, 馬などはカ ロテンは蓄積するがキサントフィルは蓄積できない。 ラットなどでは通常の条件ではほとんど蓄積がみられな い。したがって, ヒトにおけるカロテノイドの代謝や生 理活性を理解する際には, 実験動物によって得られる結 果には十分に注意する必要がある。さて, カロテノイド は, 消化による食品からの遊離, 小腸におけるミセルの 形成, 小腸上皮細胞への吸収と代謝, リンパ液への移行 等のステップを経て吸収されるものと考えられている

(Fig. 2)。まず吸収の第一段階は, カロテノイドが食 品から遊離されなければならない。精製された $\beta$ ーカロ
テンを油脂に䋰濁させたものやカプセルとして製剤化さ れたものなどは, 野菜に含まれる $\beta$-カロテンより吸収 されやすいことが知られている(1) -13)。また, 野菜でも 加熱調理することによって吸収性が高まる。たとえば， リコペンの吸収は生のトマトに比ベトマトペーストの方 が数倍良好であることが報告されている ${ }^{14)}$ 。ほうれん草 の $\beta$-カ口テンは切り刻むことによって吸収が増大し, さらに細胞壁を分解する酵素で処理し液化することに よって吸収がさらに増大することが報告されている (Table 2) ${ }^{15)}$ 。また，興味深いことに，ほうれん草に含 まれるルテインは $\beta$-カロテンと異なり油脂に懸濁した 場合と同程度に吸収され易いことが示されている。極性 の高いルテインの方が食品から遊離されやすいものと考 えられる。濃緑黄野菜では, カロテノイドはクロロプラ ストやクロモプラストなどの細胞内器官にタンパクや他 の高分子と複合体を形成したり結晶状態となって存在し ている。加熱調理によって, 細胞壁などの機械的な構造 を破壊し，また，会合するタンパク質等を変性させたり することによって消化性が向上するものと考えられる。

疎水性の高いカロテノイドが効率よく吸収されるため には, 食品から遊離された後, さらに消化管内で十分に 分散される必要がある。他の脂溶性ビタミンと同様に, 油脂の撕取がカロテノイドの吸収を促進することはよく 知られている。油脂の搷取によって胆汁の分泌が促進さ れ, 踈水性のカロテノイドが消化管内でよく分散され吸 収が促進されるものと考えられる。分散されたカロテノ イドは最終的には胆汁酸, モノアシルグリセリン, 脂肪 酸, リン脂質から構成されるミセルに組み込まれ小腸上

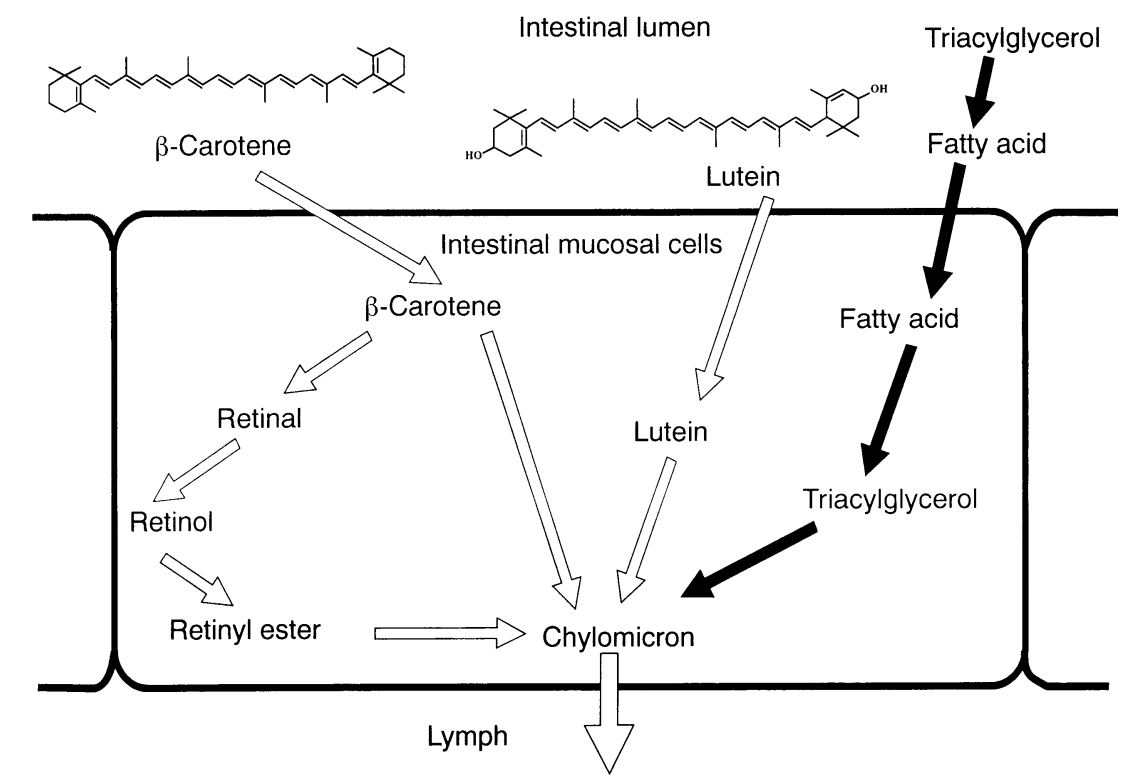

Fig. 2 Absorption and Metabolism of Carotenoids in Intestine. 
Teble 2 Increased Levels of Plasma $\beta$-Carotene and Lutein in Healthy Subjects Fed Various Spinach Products.

\begin{tabular}{|c|c|c|c|c|c|}
\hline & Control & $\begin{array}{l}\text { Carotenoid } \\
\text { suspension in } \\
\text { oil }\end{array}$ & $\begin{array}{l}\text { Whole leaf } \\
\text { spinach }\end{array}$ & Minced spinach & $\begin{array}{l}\text { Liquefied } \\
\text { spinach }\end{array}$ \\
\hline \multicolumn{6}{|c|}{$\begin{array}{l}\text { Daily intake of } \\
\text { carotenoids }(\mathrm{mg} / \mathrm{d})\end{array}$} \\
\hline$\beta$-Carotene & 0.5 & 9.8 & 10.4 & 8.8 & 9.0 \\
\hline Lutein & 0.5 & 6.6 & 12.6 & 11.2 & 11.3 \\
\hline \multicolumn{6}{|c|}{$\begin{array}{l}\text { Increase of } \\
\text { carotenoid in plasma } \\
(\Delta \mu \mathrm{M} / 3 \mathrm{wk})\end{array}$} \\
\hline $\begin{array}{l}\beta \text {-Carotene } \\
\text { Lutein }\end{array}$ & $\begin{array}{r}-0.021 \pm 0.130 \\
0.005 \pm 0.041\end{array}$ & $\begin{array}{l}2.608 \pm 1.0563 \\
0.765 \pm 0.204\end{array}$ & $\begin{array}{l}0.121 \pm 0.072 \\
0.680 \pm 0.318\end{array}$ & $\begin{array}{l}0.127 \pm 0.074 \\
0.691 \pm 0.228\end{array}$ & $\begin{array}{l}0.204 \pm 0.079 \\
0.735 \pm 0.181\end{array}$ \\
\hline
\end{tabular}

Modified from reference ${ }^{15)}$ (Castenmiller, 1999).

皮細胞に吸収されると考えられている。このようなカロ テノイドの乳化，ミセル化を阻害するものはカロテノイ ドの吸収を抑制する。たとえば，コレステロールの吸収 抑制剤であるコレステリルアミンはミセル形成を阻害し てカロテノイド吸収を抑制する。 $\beta$-カロテンとペクチ ンを同時に投与すると血漿 $\beta$-カロテンの応答が抑制さ れることが報告され，食物繊維がミセル形成を阻害しカ ロテノイド吸収を抑制するものと考えられている(16)。 ンカロリー代替油脂の一つである蔗糖ポリエステルの摂 取は非極性の $\beta$-カロテンやリコペンの血漿濃度を低下 させる。消化管内でカロテンが胆汁酸ミセル以外に蔗糖 ポリエステルへ可溶化して吸収が抑制されるものと考え られている ${ }^{17)}$ 。膵液りパーゼ阻害剤の投与によって $\beta^{-}$ カロテンの吸収が抑制されることも報告されている ${ }^{18)}$ 。 このように，カロテノイドの乳化とミセルへの可溶化が カロテノイド吸収に大きく影響し，この過程には抯取す る油脂が重要な役割を果たしていることが分かる。

ミセルに可溶化されたカロテノイドは小腸上皮細胞か ら吸収される。ラット小腸を用いた灌流実験やラット小 腸上皮細胞の培養系において， $\beta$-カロテンの吸収は特 異的結合タンパクを必要としない受動輸送であり濃度勾 配に沿って行われることが示唆されている ${ }^{19) .20)}$ 。従って, 小腸上皮細胞に打けるカロテノイドの吸収は，基本的に はカロテノイドの可溶化状態と小腸上皮細胞内でのカ口 テノイドの代謝に依存するものと考えられる。種々の力 ロテノイドが共存する食品を摄取したとき，カロテノイ ドの間で吸収に競合が起きる可能性が示唆されている。 たとえば， $\beta$-カロテンとルテインを同時に摄取すると $\beta$-カロテンはルティンの吸収を抑制し21)，ルテインは $\beta$-カロテンの吸収を抑制する ${ }^{22)}$ との結果が報告されてい る。一方では， $\beta$-カロテンの長期投与によって血漿中 の他のカロテノイドレベルが影響されることはないとの 報告 ${ }^{23)}$.24) もあり，カロテノイド間の競合が実際に起きて
いるのか明らかではない。

小腸上皮細胞へ吸収されたカロテノイドはカイロミク ロンへ組み込まれてからリンパ液中に分泌される。カイ ロミクロンの主成分は小腸細胞内で再合成されるトリア シルグリセリンであるため, 消化管内でのミセル化と同 様にこの段階でも脂質代謝に大きく影響されるものと考 えられる。実際, カイロミクロン生成にほとんど関与し ない中鎖トリアシルグリセリンを与えると長鎖トリグリ セリドに比べ顕著にカイロミクロン中の $\beta$-カロテン及 びレチニルエステル量が低下することが示されてい る25)。小腸上皮細胞へ吸収されたプロビタミン $\mathrm{A}$ カロ テノイドの一部は, $\beta$-カロテン-15, 15'-ジオキシゲナー ゼによって中央の二重結合で酸化開裂され二分子のレチ ナールに変換されるる2).27)。レチナールはさらにレチニル エステルまで代謝されカロテノイドと同様にカイロミク ロンに取り込まれリンパ液中に放出される。したがって, 本酵素は脊椎動物にビタミン $\mathrm{A}$ を供給する重要な酵素 であるとともに，プロビタミン A カロテノイドがその まま吸収されるかビタミン $\mathrm{A} へ$ 代謝されるかの分岐点 にあるキーエンザイムでもある。本酵素活性の調節機構 は明らかにされていないが，ビタミン A 不足で活性が 増大すること神また, 食餌タンパク質含量に依存するこ と ${ }^{29}$ が知られている。我々は, 食餌脂肪含量を上げると 活性が増大することを見出している ${ }^{30)}$ 。Fig 3 に示す ように，ラット小腸粘膜の $\beta$-カロテンジオキシゲナー セ活性は，2.5\%の大豆油を含むコントロール食グルー プと比較し，15\%のオリブ油あるいは大豆油を含む高 脂肪食を与えたグループで約 2.4 倍に増大した。このこ とは，脂肪㠌取によってカロテノイド吸収が促進された 時, ビタミン $\mathrm{A}$ をたくさん合成し貯蔵しておくという 飢餓に備えた適応ではないかと考えている。 $\beta$-カロテ ンの中央開裂によるビタミン $\mathrm{A}$ 生成の他に, $\beta$-カロテ ンの種々の二重結合を開裂し鎖長の異なる $\beta$-アポカロ 


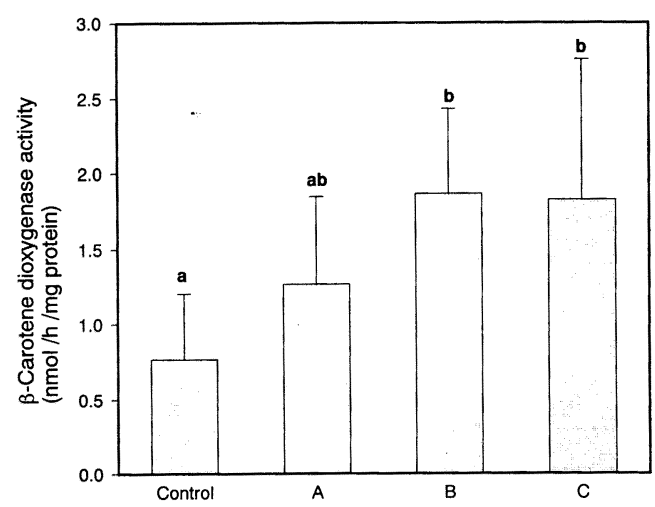

Fig. 3 Effects of Dietary Fats on $\beta$-Carotene Dioxygenase Activity of Rat Intestinal Mucosa. Control, $2.5 \%$ Soybean oil ; A, $15 \%$ Hydrogenated soybean oil ; B, $15 \%$ Olive oil ; C, $15 \%$ Soybean oil. Values not sharing a letter are significantly different $(\mathrm{P}<0.01)$

テナール及びレチナールを生成する経路（Eccentric cleavage）も提唱されているが，関与する酵素は分離さ れていない。この経路では, $\beta$ アアポカロテナールはレ チナールを経ることなく $\beta$-酸化系酵素によりレチノイ ン酸まで酸化されると報告されている。

防カロテンから合成されたレチニルエステルや未変 換のカロテノイドは小腸上皮細胞でカイロミクロンに組 み込まれリンパ液中に放出される。その後, 血流にのつ て末梢組織に運ばれ, カイロミクロン中のトリアシルグ リセリンが失われカイロミクロンレムナントとなってカ ロテノイドは肝臟に到達する。その後, 肝蔵で合成され るVLDL（超低比重リポタンパク）に組み込まれ再度 血流に放出され各組織にカロテノイドが運ばれると考え られている。ヒトでは, 肝臓, 脂肪組織以外に, 心葴, 膵臓, 脾蔵, 腎臓, 副堅, 甲状腺, 精巣, 卵巣等に力口 テノイドが集積されることが知られている。特に, 肝臓, 副腎, 精巣への蓄積が著しいとの報告もある ${ }^{31)}$ 。蓄積さ れたカロテノイドの組成は，基本的には血漿カロテノイ ド組成に類似しているが組織によって差がある。たとえ ば，精巣ではリコペンの割合が高く，網膜黄斑にはゼア キサンチンとルテインが集積されている。このような, カロテノイドの特異的な分布や細胞内の局在性と生理活 性の関係については今後の課題として残されている。

組織あるいは体液中のカロテノイドはやがては消失し ていくのであるが，その代謝分解の詳細は不明である。 一つの可能性は, 活性酸素との反応により酸化されるこ とである。Khachik 等はヒト血漿中にカロテノイドの骨 格を保持した代謝産物を検出している。リコペンの代謝 産物として 5,6-dihydroxy-5,6-dihydrolycopene を，ま
た, ルテイン/ゼアキサンチンの 4 種類の酸化産物及び 2 種類の脱水産物をヒト血漿に見出している ${ }^{32)}$ 。ヒト網 膜中にルテインの酸化産物の一つである 3-hydroxy- $\beta$. $\varepsilon$-caroten-3'-one が主要なカロテノイド代謝産物として 検出され，これらのカロテノイドが網膜で抗酸化活性を 発現している可能性が示唆されている33)。 $\beta$-カロテンか らのビタミン $\mathrm{A}$ 生成経路の一つとして提唱されている Eccentric cleavage 経路の中間体である $\beta$-アポカロテ ナールやレチナールは， $\beta$-カロテンの自動酸化によっ ても生成することが示されている ${ }^{34)}$ 。生体内に蓄積され たカロテノイドは自動酸化あるいは活性酸素との反応に より，その一部分は任意の二重結合で開裂されカルボニ ル化合物へ分解されていく可能性が高いものと考える。 生体内でこのような開裂産物が実際に生成するかは今後 の課題である。

\section{3 カロテノイドの生理活性}

\section{$3 \cdot 1$ 抗酸化活性}

カロテノイドの抗酸化活性として最も重要なものは一 重項酸素 $\left({ }^{1} \mathrm{O}_{2}\right)$ 消去活性である。基底状態の 3 重項酸 装 $\left({ }^{3} \mathrm{O}_{2}\right)$ から励起された ${ }^{1} \mathrm{O}_{2}$ は親電子付加反応を起こ しやすく, 生体成分の二重結合へのエン反応によりヒド ロペルオキシドやエンドペルオキシドなどの過酸化物を 生成する。カロテノイドの ${ }^{1} \mathrm{O}_{2}$ 消去の特徴は物理的消去 である。すなわち, 化学反応に由来せず, 一重項酸素か ら励起エネルギーを受け取ることにより励起されたカロ テノイドは熱エネルギーを放出し，それ自体はカロテノ イドにもどる。すなわち, 反応前後でカロテノイドは変 化せず何回でも ${ }^{1} \mathrm{O}_{2}$ を消去できるところに特徵がある。

$$
\begin{aligned}
& { }^{1} \mathrm{O}_{2}+\mathrm{Q} \longrightarrow{ }^{3} \mathrm{O}_{2}+\mathrm{Q} \text { (物理的消去) } \\
& { }^{1} \mathrm{O}_{2}+\mathrm{Q} \longrightarrow \mathrm{QO}_{2} \text { (化学反応) }
\end{aligned}
$$

${ }^{3} \mathrm{O}_{2}: 3$ 重項酸素 (通常の酸素), $\mathrm{Q}$ : 消去剈 $\mathrm{QO}_{2}$ : 酸化生成物

その消去活性には 9 個以上の共役二重結合が必要であ る。食物由来のカロテノイドの多くは 11 個の共役系を もつために十分な ${ }^{1} \mathrm{O}_{2}$ 消去能を有するが，両端とも非環 状構造であるリコペンの方が環状構造である $\beta$-カロテ ンよりも活性が強く，また， 4,4 位にオキソ基をもつカ ンタキサンチンやアスタキサンチンも $\beta$-カロテンより 活性が強いことが報告されている35)。血液中にはビリル

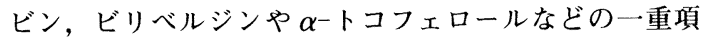
酸素消去物質が存在するが，その活性はカロテノイドに 比べはるかに弱い。しかも, その活性は主に化学的消去 に由来するため, 効率が悪い。最近 Fukuzawa ら ${ }^{36)}$ は, $\beta$-カロテンやキサントフィル類の ${ }^{1} \mathrm{O}_{2}$ 消去活性はリポ ソーム膜内ではその運動性が制限されるために溶液中の 場合の $1 / 600$ から 1/1000に低下することを示した。こ のことは, 生体膜に存在するカロテノイドの ${ }^{1} \mathrm{O}_{2}$ 消去活 
性が生理的意義を持ちうるためには, ${ }^{1} \mathrm{O}_{2}$ が発生する部 位とカロテノイドの局在する部位が近接する必要がある ことを示唆している。

生体内での ${ }^{1} \mathrm{O}_{2}$ の発生反応として知られているものに ポリフィリン症や光過敏症などを誘導する光増感酸化反 応がある。ヒト皮膚では光増感反応により生成した ${ }^{1} \mathrm{O}_{2}$ によるスクワレンヒドロペルオキシドの蓄積が報告され ている ${ }^{37)}$ 。以前から領食過程の好中球やマクロファージ

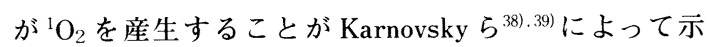
唆されていたが, 最近 Kakinuma $ら^{40)}$ は, 好中球のミエ ロペルオキシダーゼー過酸化水素一塩素イオン系が生理 的条件下で ${ }^{1} \mathrm{O}_{2}$ を放出することを直接証明した。一方, ラット心臓の虚血再環流に扔いて ${ }^{1} \mathrm{O}_{2}$ が産生されること

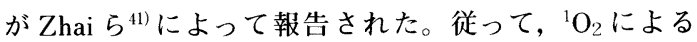
生体障害とその抑制の観点から，カロテノイドの ${ }^{1} \mathrm{O}_{2}$ 消 去能の生理的意義を再検討すべきである。

一方, 多彩な生理活性を有する一酸化絰素 $(\mathrm{NO})$ はスー パーオキシドアニオン $\left(\mathrm{O}_{2}{ }^{-}\right)$と容易に反応して酸化 障害性の強いペルオキシナイトライト $\left(\mathrm{ONOO}^{-}\right)$を発 生することが知られている。最近, $\mathrm{ONOO}^{-}$やその共役 酸であるペルオキシナイトライト酸 $(\mathrm{ONOOH})$ あるい は $\mathrm{NO}$ の酸化物である $\mathrm{NO}_{2}$ に対するカロテノイドの捕 捉消去活性が検討されており，これら NO関連活性種に 対してカロテノイドが強い反応性を有することが明らか になっている ${ }^{42) \sim 44}$ 。このことは，力ロテノイドが NO により誘導される生体障害の抑制に働く可能性を示唆し ており, 大変興味深い。ラジカル捕捉作用については, われわれが 10 年前に 4 , 4'位にオキソ基をもつカンタキ サンチンやアスタキサンチンの方が $\beta$-カロテンよりも 脂質のラジカル連鎖過酸化反応を強く抑制するが, ビタ ミン Eよりはその抑制作用は弱いことを示した ${ }^{45)}$ 。 Niki ら 4 は体鎖反応を担う脂質ペルオキシラジカル (LOO・) に対する反応性はビタミン E に比べて約 1/32であることを報告した。さらに， $\beta$-カロテンとぺ ルオキシラジカルとの反応性はアルキルラジカルやアル コキシラジカルとの反応よりも弱いことが報告されてお $り^{47)}$, 連鎖切断型抗酸化剤としてのカロテノイドの活性 はビタミン Eに比べて弱いと結論できる。従って, 力 ロテノイドのペルオキシラジカル捕捉活性が生体内で機 能するためには，ビタミン E が働きにくい部位にそれ ぞれのカロテノイドが高濃度で集積する必要がある ${ }^{48)}$ しかしながら，生体内のミク口環境においてこのような 局在性があることは未だ知られていない。

$3 \cdot 2$ LDLの酸化とカロテノイドの役割

動脈硬化の発症の初期過程で低比重リポタンパク (LDL) の酸化変性が関与することはいまでは定説と なっている。すなわち, 活性酸素種の攻撃で酸化変性し た LDL をマクロファージが貪食することから泡沫細胞
が形成されること, 酸化変性 LDL が内皮細胞を障害し 血栓生成を誘導すること, さらに活性酸素種を介して平 滑筋細胞増殖を促すことなどが挙げられる。従って, LDLの酸化変性を抑制することは動脈硬化症予防につ ながるはずであり，抗酸化剤と LDL 酸化抑制に関する 研究が国内外で活発に進行している。さて, LDL 内部 に存在する有力な抗酸化物質はビタミン Eである。し

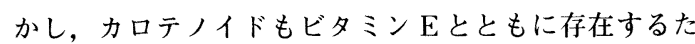
め, LDL 酸化に対するカロテノイドの作用に関する研 究成果もいくつか報告されている。Ames ら ${ }^{49)}$ のグルー プは LDL 中で発生した ${ }^{1} \mathrm{O}_{2}$ の消去に対する $\beta$-カロテン とリコペンの寄与率を $40 \%$ と見積もったが，実際にカ ロテノイドが LDL 酸化変性に対して有効であるかどう かについてはYesと Noの報告が相半ばしている50)。

Shaish $5^{51)}$ は高コレステロール負荷ウサギに $\beta$-カロ テンを同時椇取させると, 動脈硬化巣が減少することを 見出した。水溶性ラジカル発生剈で LDL を酸化させた 場合， $\beta$-カロテンを掑取したものでは，LDL 酸化に対 して特に効果はみられなかったことから， $\beta$-カロテン の抗動脈硬化作用は抗酸化とは別の活性に由来すると彼 らは考えた。われわれ济はトマトジュース捸取実験によ りカロテノイドを負荷したヒトの血漿から分画した LDLを用いた実験を行った。その結果， ${ }^{1} \mathrm{O}_{2}$ に対する LDLの抗酸化性は強化されるが, 水溶性ラジカル発生 剤で LDLを酸化させた場合においては有意な効果は認 められないことが示された（Fig. 4)。このことは， LDLの酸化防御におけるカロテノイドの役割は ${ }^{1} \mathrm{O}_{2}$ 消 去であることを示唆するものである。

さて，血漿に存在するカロテノイドは各リポタンパク 画分に存在するが，その分布は一様ではない。非極性の カロテン類やリコペン類はVLDL P LDLに分布しや すく, 極性カロテノイドであるルテインやゼアキサンチ ンはHDLに分布しやすい。このことは, 各リポタンパ クの抗酸化性にそのカロテノイドの種類が関係すること を示唆する。さらに, 食事由来のリコペンとカプサンチ ンの血漿中の蓄積量や半減期が大きく異なっており, 力 プサンチンはリコペンに比べて，多くの量が吸収される が，より速く代謝されることがわかった (Fig. 5) ${ }^{53)}$ 。 このことは, 各々のカロテノイドの生体吸収と血墏中の 蓄積代謝の様相は大きく異なることを示唆する。食品成 分としてのカロテノイドの LDLに対する抗酸化性を明 らかにするためにはこのような生体ダイナミクスを考虑 した活性評価を行う必要がある。

\section{$3 \cdot 3$ ビタミンA 活性とその他の生理活性}

脊椎動物においてカロテノイドの最も重要で不可久な 生理機能はビタミン $\mathrm{A}$ の給源となることである。 $\beta$-イ オノン環をもつ $\beta$-カロテン, $\alpha$-カロテン, $\beta$-クリプト キサンチンなどはビ夕ミン $\mathrm{A}$ へ代謝されるカロテノイ 

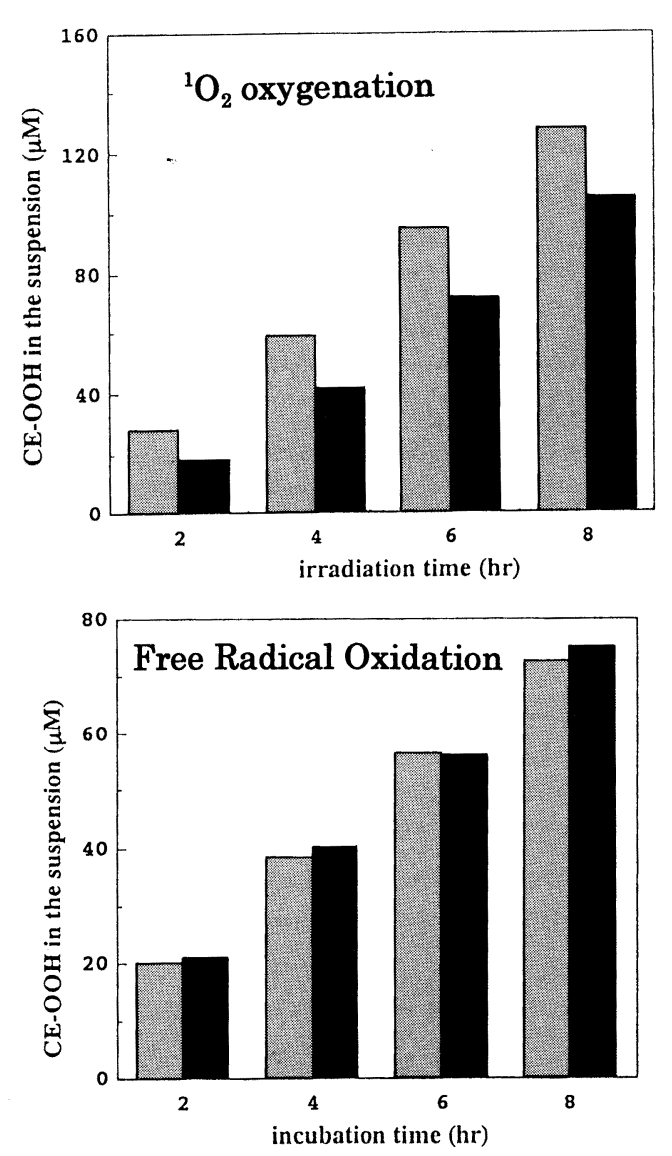

Fig. 4 Effect of Carotenoid-Supplementation on ${ }^{1} \mathrm{O}_{2}$ Oxygenation and Free Radical Oxidation of Human plasma Low-density Lipoprotein (LDL).

Dark columns ; carotenoid-supplemented LDL. Light columns ; carotenoid poor LDL. ${ }^{*} \mathrm{p}<0.05$; $* * \mathrm{p}<0.01$.

ド（プロビタミン A）である。ビタミン A は成長, 細 胞の分化, 遺伝子の転写制御等に関わっており脊椎動物 の基本的生命現象に深く関与している。また，急性骨䯣 性白血病に顕著な薬理効果を示すように, 腫瘍細胞の増 殖抑制や免疫能の増強などの薬理効果も持っている。通 常は小腸においてビタミン $\mathrm{A}$ に変換され, 血漿中のレ チノール濃度 $(1.5 \sim 2.9 \mu \mathrm{M})$ は厳密に制御されている。 通常の食事をしていると肝臓にレチノールパルミチン酸 エステルとして十分に貯蔵されている。しかし, 開発途 上国では今なお 500 万人の子供たちがビタミン A 不足 による眼乾燥症にかかり, そのうち失明, 感染症による 死亡にいたるケースが多くある現実はビタミン A，プロ ビタミン A カロテノイドの生理機能を明確に示してい ると言えよう。一方, 先進国ではカロテノイドの生理機

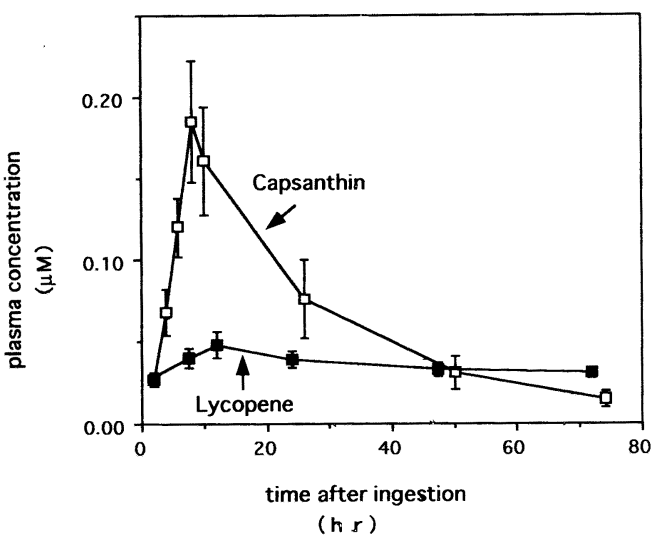

Fig. 5 Plasma Capsanthin and Lycopene Concentrations in Men after a Single Ingestion of Paprika Juice and Tomato Soup, Respectively.

能としてのビタミン $\mathrm{A}$ 作用はすでに飽和状態に達して いると考えられるので，カロテノイドのがんや疾病の予 防効果のメカニズムとしては考え難い。しかし，各組織 に蓄積されたカロテノイドが局所的にビタミン A の給 源として機能していることを示唆する報告もある。牛卵 胞には $\beta$-カロテンジオキシゲナーセが存在し, 酵素活 性と卵胞内のレチノールレベルの間に正の相関があるこ とが示され，卵胞内で $\beta$-カロテンからレチノールが供 給され繁殖に好結果を与えるものと考えられている ${ }^{54)}$ 。 食餌由来の $\beta$-カロテンは小腸に存在する $\beta$-カロテンジ オキシゲナーゼでビタミン $\mathrm{A}$ へ変換されると考えられ ているが, 卵胞にも存在するようにいろいろな蔵器に存 在する。実際に我々が調べたところ, ラット各蔵器のホ モジネートの比活性（pmol retinal/mg protein/h) は, 小腸, 肝蔵, 脳, 肺, 腎臓で, それぞれ，690，180，16， 8，1であり，小腸と肝臓に特異的に発現されてはいる がその他の臓器にも確かに活性が検出された ${ }^{55)}$ 。また, もう一つのビタミン A 生成経路として考えられている Eccentric cleavage 経路の開裂酵素活性は小腸, 肝臓, 腎臓, 脂肪組織でほぼ同等の活性が認められている ${ }^{56)}$ 。 このように各組織がビタミン A を生成する可能性を秘 めているので, 各組織に蓄積されるプロビタミン A が その組織においてビタミン A の給源となる可能性が考 えられる。また，すでに触れたように各組織でカロテノ イドの自動酸化あるいは活性酸素との反応で Eccentric cleavage 産物が生成する可能性も考えられるので, ビ夕 ミンAのみならず非プロビタミン A からレチノイド様の 物質が生成し, 何らかの影響を細胞に与える可能性が考 えられる。実際, Nikawa $5^{57)}$ は非プロビタミンAの一 つであるカンタキサンチンが動物細胞培養液中で酸化さ れ4-oxo-retinoic acid が生成し，これが細胞に組み込ま 
れた RAR $\beta$ プロモーターのレポーター遺伝子を活性化 することを示している。また， $\beta$-カロテンの酸化産物 である 5,8-endoperoxy-2,3-dihydro- $\beta$-apocarotene-13one が乳がん細胞の増殖抑制活性を示すことも報告され ている ${ }^{58)}$ このように, カロテノイドから生体内で生成 する様々な分解物や代謝産物に機能が見出される可能性 が考えられる。

カロテノイドの抗腫瘍作用等のメカニズムは細胞への 作用から少しずつ明らかにされ始めている。ハワイ大学 のBertram ${ }^{59)}$ は, 非プロビタミン A カロテノイドを含む 種々のカロテノイドが細胞間の Gap junctional communicationを増強することをがん予防効果のメカニズム として提唱した。隣接する細胞との接着部位でギャップ 結合が形成されこの結合部位には細孔があり低分子物質 が透過することができる。この結合を通しての細胞間の 相互作用が組織の恒常性を維持するために必要とされ, この相互作用が低下するとがん細胞の増殖が促進される ものと考えられている年。 Table 3 には，マウス繊維芽 細胞 $\mathrm{C} 3 \mathrm{H} / 10 \mathrm{~T} 1 / 2$ におけるカロテノイドによる Gap junctional communicationの誘導とその他の活性との関 係が示されている。 $\beta$-カロテン, カンタキサンチン, ルテイン，リコペンに Gap junctional communicationの 誘導が認められ, C $3 \mathrm{H} / 10 \mathrm{~T} 1 / 2$ 細胞のメチルコラントレ ンによる悪性形質転換を抑制する活性と高い相関性が認 められている。また, Gap junctional communicationの 誘導活性はプロビタミン $\mathrm{A}$ 活性や脂質過酸化阻害活性 と関連しないものであることが分かる。この誘導は， ギャップ結合のタンパク質をコードする遺伝子 connexin43 の発現の増大によるものであることが明ら かにされている ${ }^{61)}$ 。レチノイン酸にも同様な作用が認め られ， $\beta$-カロテンの作用はレチノイン酸が関与してい る可能性が高い62)。カンタキサンチンについては, 4-oxo-retinoic acid が Gap junctional communication 誘導すること ${ }^{63)}, 4^{-}$oxo-retinoic acid がカンタキサンチ
ンの酸化分解によって生成すること ${ }^{57)}$ が示されているの で, カンタキサンチンの作用の一部は 4-oxo-retinoic acid が関与している可能性が高いものと考えられる。 1991 年の Bertram 等の報告以後, Table 4 に示すよう にがん由来細胞株等に対するカロテノイドの分化誘導や 増殖抑制作用が報告されてきている。ヒト子宮頸部異形 成由来細胞株に対して $\beta$-カロテンが EGF (表皮増殖因 子）レセプターの発現を抑制し細胞增殖を抑制すること が見出されるなど ${ }^{67)}$, 細胞生物学的研究による作用機構 の解明が期待される。抗腫瘍作用以外に，イソプレノイ ドとしてカロテノイドがコレステロール生合成を調節す る作用を持つことが最近報告された。 $\beta$-カロテン及び リコペンはマクロファージのコレステロール生合成を抑 制しまた LDL レセプター活性を増大させる作用を持つ ことが示され，実際にリコペンをヒトに投与すると血清

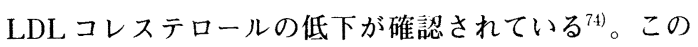
ように近年, 培養細胞系でのカロテノイドの作用に関す る報告が増えているが, in vivo での生理活性がこのよ うな細胞レベルでの作用機構から裏付けられることを期 待したい。

\section{4 ま と}

カロテノイドの研究は, 疫学調查によるがん予防物質 としての期待から爆発的に研究が進んだが, 現在でもそ の機能が十分に理解されているとはいえない。ヒトは日 常の食物を通じて様々な種類のカロテノイドを攝取して いる。現在, 疾患予防が期待される食品中の新規微量成 分として様々な物質が提出されているが, ヒトでの腸管 吸収機構や各組織への蓄積量がカロテノイドほど明確な ものはない。今後カロテノイドの生理機能の全体像がヒ トにおいて明らかなものとなることを期待する。

(受付：1999 年 7 月 6 日, 受理 : 1999 年 8 月 12 日)

Table 3 Comparison of Biological Properties of Carotenoids.

\begin{tabular}{|c|c|c|c|c|}
\hline Compounds & Provitamin A & $\begin{array}{l}\text { Inhibition of } \\
\text { chemically } \\
\text { induced } \\
\text { transformation }\end{array}$ & $\begin{array}{l}\text { Induction of } \\
\text { gap junctional } \\
\text { communication }\end{array}$ & $\begin{array}{l}\text { Relative } \\
\text { inhibition of } \\
\text { lipid } \\
\text { peroxidation }\end{array}$ \\
\hline$\beta$-Carotene & +++ & ++++ & ++++ & ++ \\
\hline Canthaxanthin & - & $+t+t$ & ++++ & $++t$ \\
\hline Lutein & - & + & $++t$ & $++t$ \\
\hline$\alpha$-Carotene & ++ & ++ & + & + \\
\hline Lycopene & - & + & ++ & ++ \\
\hline m-Bixin & - & - & - & +++ \\
\hline$\alpha$ - Tocopherol & & + & \pm & $++t+$ \\
\hline
\end{tabular}

Modified from reference ${ }^{59)}$ (Zhang, 1991) 
Table 4 Biological Effects of Carotenoids on Various Cell Lines.

\begin{tabular}{|c|c|c|c|}
\hline Carotenoids & Cell line & Biological effects & $\begin{array}{l}\text { First author, year of } \\
\text { publication } \\
\text { (reference No.) }\end{array}$ \\
\hline $\begin{array}{l}\text { Dimethylcrocetin } \\
\text { Crocetin } \\
\text { Crosin }\end{array}$ & $\begin{array}{l}\text { HL- } 60 \text { Human } \\
\text { promyelocytic } \\
\text { leukemia cell line }\end{array}$ & $\begin{array}{l}\text { Inhibition of cell } \\
\text { proliferation } \\
\text { Induction of cell } \\
\text { differentiation }\end{array}$ & Tarantilis, 1994 (64) \\
\hline $\begin{array}{l}\beta \text { - Carotene } \\
\text { Canthaxanthin }\end{array}$ & $\begin{array}{l}\text { MCF-10A Human } \\
\text { mammary epithelial } \\
\text { cell }\end{array}$ & $\begin{array}{l}\text { Induction of cell } \\
\text { differentiation }\end{array}$ & Rock, 1995 (65) \\
\hline Lycopene & $\begin{array}{l}\text { Ishikawa Human } \\
\text { endometrial cancer } \\
\text { cell }\end{array}$ & $\begin{array}{l}\text { Inhibition of cell } \\
\text { proliferation }\end{array}$ & Levy, 1995 (66) \\
\hline$\beta$-Carotene & $\begin{array}{l}\text { Human cervical } \\
\text { dysplasia-drived } \\
\text { cell lines }\end{array}$ & $\begin{array}{l}\text { Inhibition of cell } \\
\text { proliferation } \\
\text { Down-regulation of } \\
\text { EGF receptor }\end{array}$ & Muto, 1995 (67) \\
\hline $\begin{array}{l}\beta \text { - Carotene } \\
\alpha \text { - Carotene } \\
\text { Lutein } \\
\text { Lycopene } \\
\text { Fucoxanthin } \\
\text { Canthaxanthin } \\
\text { Astaxanthin }\end{array}$ & Mouse hepatocytes & $\begin{array}{l}\text { Suppression of } \\
\text { microcystin-induced } \\
\text { morphological } \\
\text { changes }\end{array}$ & $\begin{array}{l}\text { Matsushima- } \\
\text { Nishiwaki, } 1995 \\
\text { (68) }\end{array}$ \\
\hline $\begin{array}{l}\beta \text {-Carotene } \\
\text { Lutein }\end{array}$ & $\begin{array}{l}\text { HL- } 60 \text { Human } \\
\text { promyelocytic } \\
\text { leukemia cell line }\end{array}$ & $\begin{array}{l}\text { Induction of cell } \\
\text { differentiation }\end{array}$ & $\begin{array}{l}\text { Gross, } 1997 \text { (69) } \\
\text { Biesalski, } 1997 \text { (70) }\end{array}$ \\
\hline $\begin{array}{l}\alpha-\text { Carotene } \\
\beta-\text { Carotene } \\
\text { Canthaxanthin }\end{array}$ & $\begin{array}{l}\text { DLD-1 and Colo } \\
320 \text { D Human } \\
\text { colon cancer cell } \\
\text { lines }\end{array}$ & $\begin{array}{l}\text { Inhibition of cell } \\
\text { proliferation }\end{array}$ & Onogi, 1998 (71) \\
\hline Lycopene & $\begin{array}{l}\text { DU-145 and PC-3 } \\
\text { Human prostate } \\
\text { carcinoma cell lines }\end{array}$ & $\begin{array}{l}\text { Synergistic } \\
\text { inhibition of cell } \\
\text { proliferation with } \\
\alpha \text { - tocopherol }\end{array}$ & Pastori, 1998 (72) \\
\hline Canthaxanthin & $\begin{array}{l}\text { Human WiDr colon } \\
\text { adenocarcinoma cell } \\
\text { line, } \\
\text { SK-MEL-2 Human } \\
\text { melanoma cell line }\end{array}$ & $\begin{array}{l}\text { Inhibition of cell } \\
\text { proliferation } \\
\text { Induction of } \\
\text { apoptosis }\end{array}$ & Palozza, 1998 (73) \\
\hline $\begin{array}{l}\beta \text { - Carotene } \\
\text { (Oxidation } \\
\text { products) }\end{array}$ & $\begin{array}{l}\text { MCF-7 Human } \\
\text { breast cancer cell }\end{array}$ & $\begin{array}{l}\text { Inhibition of cell } \\
\text { proliferation }\end{array}$ & $\mathrm{Hu}, 1998$ (58) \\
\hline
\end{tabular}

\section{文献}

1) F. Khachick, C. J. Spangler, J. C. Smith Jr, L. M. Canfield, A. Steck, H. Pfander, Anal. Chem., 69, 1873 (1992).

2) J. M. Seddon, U. A. Ajani, R. D. Sperduto, R.
Hiller, N. Blair, T. C. Burton, M. D. Farber, E. S. Gragoudas, J. Haller, D. T. Miuller, L. A. Yannuzzi, W. Lillet, J. Am. Med. Assoc., 272, 1413 (1994).

3) C. S. Foote, R. W. Denny, J. Am. Chem. Soc., 90, 5216 (1968).

4) N. Krinsky, Pure and Appl. Chem., 51, 649 (1979). 
5) R. Peto, R. Doll, J. D. Buckley, M. B. Sporn, Nature, 290, 201 (1981).

6) G. W. Burton, K.U. Ingold, Science, 224, 569 (1984).

7) W. J. Blot et al., J. Natl.Cancer Inst. 85, 1484 (1993).

8) M. Rapla, J. Virtamo, S. Ripatti, J. K. Huttunen, D. Albanes, P. R. Taylor, Lancet, 349, 1715 (1997).

9) G. S. Omen, G. E. Goodman, M. D. Thornquist, Balmes, J. M. R. Cullen, A.Glass et al., New Engl. J. Med., 334, 1150 (1996).

10) C. H. Hennekens et al., New Engl. J. Med. 334, 1145 (1996).

11) R. Torronen, M. Lehmusaho, S. Hakkinen, $O$. Hanninen, H. Mykkanen, Nutr. Res., 16, 565 (1996).

12) S. Depee, C. E. West, C. E. Muhilal, D. Karyadi, D. J. G. A. J. Hautvast, Lancet, 346, 75 (1995).

13) J. Bulux, J. Q. Deserrano, A. Giuliano, R. Perez, C. Y. Lopez, C. Rivera, N. W. Solomons, L. M. Canfield, Am. J. Clin. Nutr., 59, 1369 (1994).

14) C. Gartner, W. Stahl, H. Sies, Am. J. Clin. Nutr., 66, 116 (1997).

15) J. J. M. Castenmiller, C. E. West, J. P. H. Linssen, K. H. Hof, A. G. J. Voragen, J. Nutr. 129, 349 (1999).

16) C. L. Rock, M. E. Swendseid, R. A. Jacob, R. W. Mckee, Am. J. Clin. Nutr., 55, 96 (1992).

17) J. A. Weststrate, K. H. Hof, Am. J. Clin. Nutr., 62, 591 (1995).

18) J. G. Zhi, A. T. Melia, S. G. Kosstwardy, S. Arora, I. H. Patel, J. Clin. Pharm., 36, 152 (1996).

19) D. Hollander, P. E. Rubler, Am. J. physiol., 233, E686 (1978).

20) G. Scita, G. W. Aponte, G. Wolf, J. Nutr. Biochem., 3, 118 (1992).

21) H. Berg, T. Vliet, Am. J. Clin. Nutr., 68, 82 (1998).

$22)$ D. Kostic, W. S. White, J. A. Olson, Am. J. Clin. Nutr., 62, 604 (1995).

23) S. T. Mayne, B. Cartmel, F. Silva, C. S. Kim, B. G. Fallon, K. Briskin, T. Z. Zheng, M. Baum, G. Shorposner, W. J. Goodwin, Am. J. Clin. Nutr., 68, 642 (1998).

24) D. W. Nierenberg, B. J. Dain, L. A. Mott, J. A. Baron, E. R. Greenberg, Am. J. Clin. Nutr., 66, 315 (1997).

25) P. Borel, V. Tyssandier, N. Mekki, P. Grolier, Y. Rochette, M. C. Alexandregouabau, D. Lairon, V. Azaisbraesco, J. Nutr., 128, 1361 (1998).

26) D. S. Goodman, J. A. Olson, Methods in Enzymology, 15, 462 (1969).

27) A. Nagao, A. During, C. Hoshino, J. Terao, J. A. Olson, Arch. Biochem. Biophys., 328, 57 (1996).

28) T. Vliet, M. F. Vlissingen, F. Schaik, H. Berg, J.
Nutr., 126, 499 (1996).

29) A. G.-Senger, G. Wolf, J. Nutr., 100, 300 (1970).

30) A. During, A. Nagao, J. Terao, J. Nutr., 128, 1614 (1998).

31) W. Stahl, W. Schwarz, A. R. Sundquist, H. Sies, Arch. Biochem. Biophys., 294,173 (1992).

32) F. Khachik, G. R. Beecher, J. C. Smith, J. Cell Biochem., 22, 236 (1995).

33) F. Khachik, P. S. Bernstein, D. L. Garland, Invest. Ophthalmol. Vis. Sci. 38, 1802 (1997).

34) R. C. Mordi, J. C. Walton, G. W. Burton, L. Hughes, K. U. Ingold, D. A. Lindsay, D. J. Moffatt, Tetrahedron, 49, 911 (1993).

35) P. Dimascio, S. Kaiser, H. Sies, Arch, Biochem. Biophys., 274, 532 (1989).

36) K. Fukuzawa, Y. Inokami, A. Tokumura, J. Terao, A. Suzuki, Lipids, 33, 751 (1998).

37) 河野善行, 阪本興彦, 中村哲治, 宮澤陽夫、油化学, 42, 204 (1993).

38) M. J. Steinbeck, A. U. Khan, M. J. Karnovsky, J. Biol. Chem., 268, 15649 (1993).

39) M. J. Steinbeck, A. U. Khan, M. J. Karnovsky, J. Biol. Chem., 267, 13415 (1992).

40) C. Kiryu, M. Makiuchi, J. Miyazaki, T. Fukunaga, K. Kakinuma, FEBS Lett., 443, 154 (1999).

41) X. Zhai, M. Ashraf, J. Am. Physiol., H1229 (1995).

42) K. Kikugawa, K. Hiramoto, S. Tomiyama, Y. Asano, FEBS Lett., 404, 175 (1997).

43) S. M. Khopde, K. I. Priyadarsini, T. Mukherjee, P. B. Kulkarni, J. G. Satav, R. K. Bhattachrya, Free Radical Biol. Med., 25, 66 (1998).

44) R. Scheidegger, A. K. Pande, P. L. Bounds, W. H. Koppenol, Nitric Oxide, 2, 8 (1998).

45) J. Terao, Lipids, 24, 659 (1989).

46) H. Tsuchihashi, M. Kigoshi, M. Iwatsuki et al., Arch. Biochem. Biophys., 323, 137 (1995).

47) L. Mortensen, H. Skibsted, FEBS Lett., 426, 392 (1998).

48) P. L. Boey, A. Nagao, J. Terao et al., Biochim. Biophys. Acta., 1126, 178 (1992).

49) R. Wagner, P. A. Motchnik, R. Stcker, H. Sies, B. N. Ames, J. Biol. Chem., 268, 18502 (1993).

50) 寺尾純二, ビタミン, 72, 395 (1998).

51) A. Shaish, A. Daugherty, F. O'sullivan, G. Schonfeld, J. W. Heinecke, J. Clin. Invest., 96, 2075 (1995).

52) S. Oshima, F. Ojima, H. Samamoto, Y. Ishiguro, J. Terao, J. Agric. Food Chem., 44, 2306 (1996).

53) S. Oshima, H. Sakamoto, Y. Ishiguro, J. Terao, $J$. Nutr. 127, 1475 (1997).

54) F. J. Schweigert, M. Wierich, W. A. Rambeck, H. Zucker, Theriogenology, 30, 923 (1988).

55) A. During, A. Nagao, C. Hoshino, J. Terao, Anal. Biochem., 241, 199 (1996).

56) X.-D. Wang, G.-W. Tang, J. G. Fox, N. I. Krinsky, 
R. M. Russell, Arch. Biochem. Biophys., 285, 8 (1991).

57) T. Nikawa, W. A. Schulz, C. E. Brink, M. Hanusch, P. Saag, W. Stahl, H. Sies, Arch. Biochem. Biophys., 316, 665 (1995).

58) X. Hu, K. M. White, N. E. Jacobsen, D. J. Mangelsdorf, L. M. Canfield, J. Nutr. Biochem., 9, 567 (1998).

59) L.-X. Zhang, R. V. Cooney, J. S. Bertram, Carcinogenesis, 12, 2109 (1991).

60) H. Yamasaki, Carcinogenesis, 11, 1051 (1990).

61) L.-X. Zhang, R. V. Cooney, J. S. Bertram, Cancer Res., 52, 5707 (1992).

62) P. Acevedo, J. S. Bertram, Carcinogenesis, 16, 2215 (1995).

63) M. Hanusch, W. Stahl, W. A. Schulz, H. Sies, Arch. Biochem. Biophys., 317, 423 (1995).

64) P. A. Tarantilis, H. Morjani, M. Polissiou, M. Manfait, Anticancer Res., 14, 1913 (1994).

65) C. L. Rock, R. A. Kusluski, M. M. Galvez, S. P. Ethier, Nutr. Cancer, 23, 319 (1995).

66) J. Levy, E. Bosin, B. Feldman, Y. Giat, A.
Miinster, M. Danilenko, Y. Sharoni, Nutr. Cancer, 24, 257 (1995).

67) Y. Muto, J. Fujii, Y. Shidoji, H. Moriwaki, T. Kawaguchi, T. Noda, Am. J. Clin. Nutr., 62, S1535 (1995).

68) R. M.-Nishiwaki, Y. Shidoji, S. Nishiwaki, T. Yamada, H. Moriwaki, Y. Muto, Lipids, 30, 1029 (1995).

69) M. D. Gross, T. D. Bishop, J. D. Belcher, D. R. Jacobs, Nutr. Cancer, 27, 169 (1997).

70) H. K. Biesalski, M. Schaffer, Internat. J. Vit. Nutr. Res., 67, 357 (1997).

71) N. Onogi, M. Okuno, R. M-Nishiwaki, Y. Fukutomi, H. Moriwaki, Y. Muto, S. Kojima, Nutr. Cancer., 32, 20 (1998).

72) M. Pastori, H. Pfander, D. Boscoboinik, A. Azzi, Biochem. Biophys. Res. Commun., 250, 582 (1998).

73) P. Palozza, N. Maggiano, G. Calviello, P. Lanza, E. Piccioni, F. O. Ranelletti, G. M. Bartoli, Carcinogenesis, 19, 373 (1998).

74) B. Fuhrman, A. Elis, M. Aviram, Biochem. Biophys. Res. Commun., 233, 658 (1997). 


\title{
[総説］ビタミン Eによる食品品質改良 \\ 中 村 哲也 \\ 芝浦工業大学工学部自然科学教室 (化学) \\ （３30-8570 埼玉県大宮市深作溜井原 307）
}

ビタミン E 同族体の抗酸化活性順がインビトロとインビボで必ずしも一致しないのは長い間にわたり議論の的 であった。最近のビタミン $\mathrm{E}$ 代謝研究で肝臓には $\alpha$-トコフェロール輸送タンパクが存在していて非 $\alpha$-トコ フェロールに対して $\alpha$-トコフェロールを優位として利用する機構のあることが明らかになった。この知見は食 品化学分野におけるビ夕ミン $\mathrm{E}$ 同族体の活性比の説明にも示唆を与えている。

ビタミン E の生物活性は種々の生体の還元性物質との相乗作用によっていることが明瞭になってきた。そこで インビボのビ夕ミン E をはじめとする抗酸化ネットワークの解明はシネルギストの創出に貢献するであろう。ト コフェロキシルラジカルからビタミン E をいかに再生させるかの検討は食品化学において優れたシネルギストを 見い出すための有力な手段である。

最近の食品䇽よび油脂へのビタミン $\mathrm{E}$ 応用例を紹介した。

（連絡者：中村哲也）Vol.48, No.10, 1067 (1999)

[総説 $]$

\section{カロテノイドの吸収代謝と生理活性}

\author{
寺尾 純二*1 ・ 長尾 昭 彦*2 \\ * 1 徳島大学医学部栄養学科食品学講座 \\ （７70-8503 徳島県徳島市蔵本町 3-18-15） \\ * 2 農林水産省食品総合研究所食品理化学部脂質研究室 \\ （テ 305-8642 茨城県つくば市観音台 2-1-2）
}

食事中に含まれるカロテノイドは消化管から吸収され，体内の各組織に蓄積することが知られている。しかし， その生理機能については, プロビタミン A 活性以外は明らかではない。フリーラジカル捕捉や一重項酸素消去な どカロテノイドの抗酸化作用はよく研究されている。しかし，この抗酸化活性が生体内に存在する抗酸化防御系 にどの程度寄与するかは明確ではない。

一方, 動物実験におけるカロテノイドの抗腫瘍効果は, 細胞増殖抑制や細胞分化誘導作用で説明される。また, 細胞間ギャップ結合を強めることもその抗腫瘍効果に関与する可能性がある。食事由来のカロテノイドの生理機 能を評価するためには，その吸収と代謝を理解することが重要である。ビタミン A 活性発現に必要な 15,15 ' ジオキシゲナーゼは生体組織に広く分布し, 消化管からのカロテノイドの吸収は食事に含まれる共存物により大 きく影響される。さらに，その代謝経路は，酸化反応プロセスが示唆されているものの，まだ明らかにされてい ない。

（連絡者：寺尾純二) Vol.48, No.10, 1075 (1999) 